\title{
Pemilihan Prioritas Penanganan Banjir Di Kecamatan Bogor Tengah Kota Bogor Provinsi Jawa Barat
}

\author{
Fahmi Nur Rahman ${ }^{1^{*}}$, Eka Wardhani ${ }^{2}$ \\ 1,2 Jurusan Teknik Lingkungan Fakultas Teknik Sipil dan Perencanaan Institut Teknologi Nasional, Jalan \\ PHH.Mustofa No.23, Bandung 40124, Indonesia \\ *Koresponden email: fahminurrahman44@gmail.com
}

Diterima: 26 Desember 2019

Disetujui: 14 Maret 2020

\begin{abstract}
As time goes, the pace of growth and social functioning of the physical and socio-economic areas of Jabodetabek (Jakarta, Bogor, Depok, Tangerang, and Bekasi) experienced rapid development, so the policy of national spatial and policy The provincial spatial of West Java emphasized the need for adequate infrastructure development to make the city of Bogor ideal as a buffer area (hinterland) of DKI Jakarta. Referring to the condition of development dynamics of Bogor City, two important things to consider are changes in land use and spatial planning, because city drainage problems arise due to these changes. then to anticipate these problems, it is necessary to immediately review the Bogor City drainage masterplan, and it is necessary to study the material and formulate alternative solutions in the area that will be prioritized for handling. This study aimed to discuss about the arrangement of areas that will be prioritized for handling, based on Peraturan Menteri Pekerja Umum No. 12 Tahun 2014 about concerning Procedures for Planning a City Drainage System. This study can be used as a recommendation to determine priority areas for Central Bogor District.
\end{abstract}

Keywords: Drainage, flood, Bogor Tengah District, Masterplan, Hinterland

\begin{abstract}
Abstrak
Seiring berjalannya waktu, laju pertumbuhan dan alih fungsi lingkungan fisik maupun sosial ekonomi di kawasan Jabodetabek (Jakarta, Bogor, Depok, Tangerang dan Bekasi) mengalami perkembangkan yang pesat, sehingga kebijakan Tata Ruang Nasional maupun kebijakan Tata Ruang Provinsi Jawa Barat menekankan perlunya pembangunan infrastruktur yang memadai guna menjadikan kota Bogor ideal sebagai kawasan penyangga (hinterland) Provinsi DKI Jakarta. Merujuk pada kondisi dinamika pembangunan Kota Bogor saat ini, dua hal penting yang harus diperhatikan adalah perubahan tata guna dan tata ruang wilayah, karena permasalahan drainase kota muncul akibat adanya perubahan tersebut. Maka untuk mengantisipasi resiko tambahan dari berubahnya tata ruang dan tataguna wilayah Kota Bogor, perlu segera dilakukan peninjauan kembali terhadap masterplan drainase Kota Bogor, serta dilakukannya pendalaman kajian materi dan perumusan alternatif solusi pada kawasan yang akan dijadikan prioritas penanganan. Penelitian ini bertujuan untuk membahas tentang penyusunan kawasan yang akan dijadikan prioritas penanganan berdasarkan Peraturan Menteri Pekerja Umum No. 12 tahun 2014 tentang tata cara perencanaan sistem drainase perkotaan. Penelitian ini diharapkan dapat dijadikan rekomendasi penentuan kawasan prioritas penanganan banjir di Kecamatan Bogor Tengah.
\end{abstract}

Kata Kunci: Drainase, Banjir, Kecamatan Bogor Tengah, Masterplan, Hinterland

\section{Pendahuluan}

Meningkatnya perkembangan dikawasan perkotaan menimbulkan permasalahan genangan air, banjir, dan pencemaran air. Pertumbuhan penduduk yang signifikan menyebabkan kepadatan penduduk, sehingga menyebabkan tekanan terhadap ruang dan lingkungan. Hal tersebut berdampak pada berkurangnya sarana dan pra-sarana pengendali banjir, seperti kurangnya kemampuan saluran drainase dalam menampung kelebihan limpasan air dipermukaan [1].

Selaras dengan pesatnya laju pertumbuhan dan alih fungsi fisik maupun sosial ekonomi kawasan Kota Bogor, kebijakan Pemerintah Kota Bogor menekankan perlunya pembangunan infrastruktur yang memadai guna menjadikan Kota Bogor ideal sebagai kawasan penyangga [2]. Kota Bogor merupakan bagian tengah dari daerah aliran sungai Cisadane dan Ciliwung. Menurut Ref [3] dalam [4] menyebutkan 
bahwa tingginya curah hujan di Kota Bogor serta berubahnya alih fungsi lahan di kawasan tersebut menyebakan meningkatnya laju limpasan permukaan sehingga menyebabkan banjir pada daerah lain. Bagian tengah DAS Ciliwung merupakan kawasan yang paling besar menyebabkan banjir di beberapa kawasan di Jakarta.

Penelitian [5] memaparkan, limpasan air permukaan dipengaruhi oleh berbagai faktor seperti, topografi, tata guna lahan, serta luas dan bentuk daerah pengaliran. Adapun faktor lainya yaitu faktor meterologi meliputi intensitas, distribusi curah hujan dan durasi hujan pada kawasan tersebut. Untuk kasus di Kecamatan Bogor Tengah, faktor utama yang mempengaruhi terjadinya banjir dikawasan tersebut adalah perubahan tata guna lahan, kapasitas saluran drainase terlampaui, serta terdapatnya sampah pada saluran drainase yang menyebabkan terjadinya penyumbatan aliran.

Menurut [6] secara konseptual proses perubahan tata guna lahan dipinggiran kota dipengaruhi oleh berbagai hal antara lain secara aktif kota menjadi bahan pertimbangan bagi pengusaha untuk dibeli dan dikembangkan, kota mulai diprogramkan untuk pembangunan, dibangun dan dihuni oleh penduduk, serta adanya urban interest (bergesernya tata guna lahan pinggiran kota yang tersedia akibat meningkatnya kebutuhan lahan kota dalam hal pengembangan pembangunan)

Penelitian ini dilakukan berdasarkan hasil studi literatur serta pengamatan langsung di lapangan guna melihat kawasan terdampak banjir yang perlu dijadikan kawasan prioritas penanganan banjir. Tujuan dari penelitian ini yaitu untuk memberikan rekomendasi pemilihan prioritas penanganan banjir di Kecamatan Bogor Tengah berdasarkan Permen PU No. 12 tahun 2014.

\section{Metode Penelitian}

Banjir dapat menyebabkan kerugian fisik maupun material, banjir merupakan bencana alam yang disebabkan oleh curah hujan yang tinggi namun tidak diimbangi dengan kemampuan saluran drainase dalam menampung kelebihan limpasan tersebut. Penelitian [7] menyatakan terlampauinya kapasitas sungai disebabkan oleh berlebihnya air yang menggenang disuatu kawasan yang biasanya kering, menyebabkan kapasitas sungai sehingga tidak mampu menampung kelebihan air tersebut. Kejenuhan tanah yang terlampaui serta masih tingginya ketinggian muka air didalam alur sungai merupakan dua faktor yang menyebabkan banjir pada saat tingginya curah hujan.

Kerentanan banjir merupakan tingkat kemudahan suatu kawasan untuk terkena banjir. Daerah dengan relief datar dan landai seperti dataran nyarit, dataran alluvial, teras marin, dan teras sungai erosional, merupakan daerah yang mudah terkena dampak pada saat banjir [8].

Penentuan skala prioritas dengan menggunakan metode Permen PU No. 12 tahun 2014 yang digunakan pada penulisan ini digunakan juga oleh [9] dalam menentukan prioritas penangaan banjir di Kecamatan Bogor Selatan, dimana hasil dari penelitianya diperoleh Kelurahan Cikaret sebagai prioritas penaganan banjir karena memperoleh nilai skoring $>200$.

Penelitian ini dilakukan di Kecamatan Bogor Tengah untuk mengetahui prioritas penanganan banjir berdasarkan Permen PU No. 12 tahun 2014. Adapun metodologi penelitian dapat dilihat pada Gambar 1. Evaluasi saluran drainase di Kecamatan Bogor Tengah menggunakan kriteria skoring genangan berdasarkan PerMen PU No. 12 tahun 2014 tentang perencanaan drainase perkotaan. Setiap kondisi kriteria genangan memiliki nilai dan pembobotan sebagaimana dapat dilihat pada Tabel 1,2,4, 5,7 dan 8 . Parameter penentuan prioritas penanganan meliputi beberapa hal seperti dijabarkan pada uraian selanjutnya. 


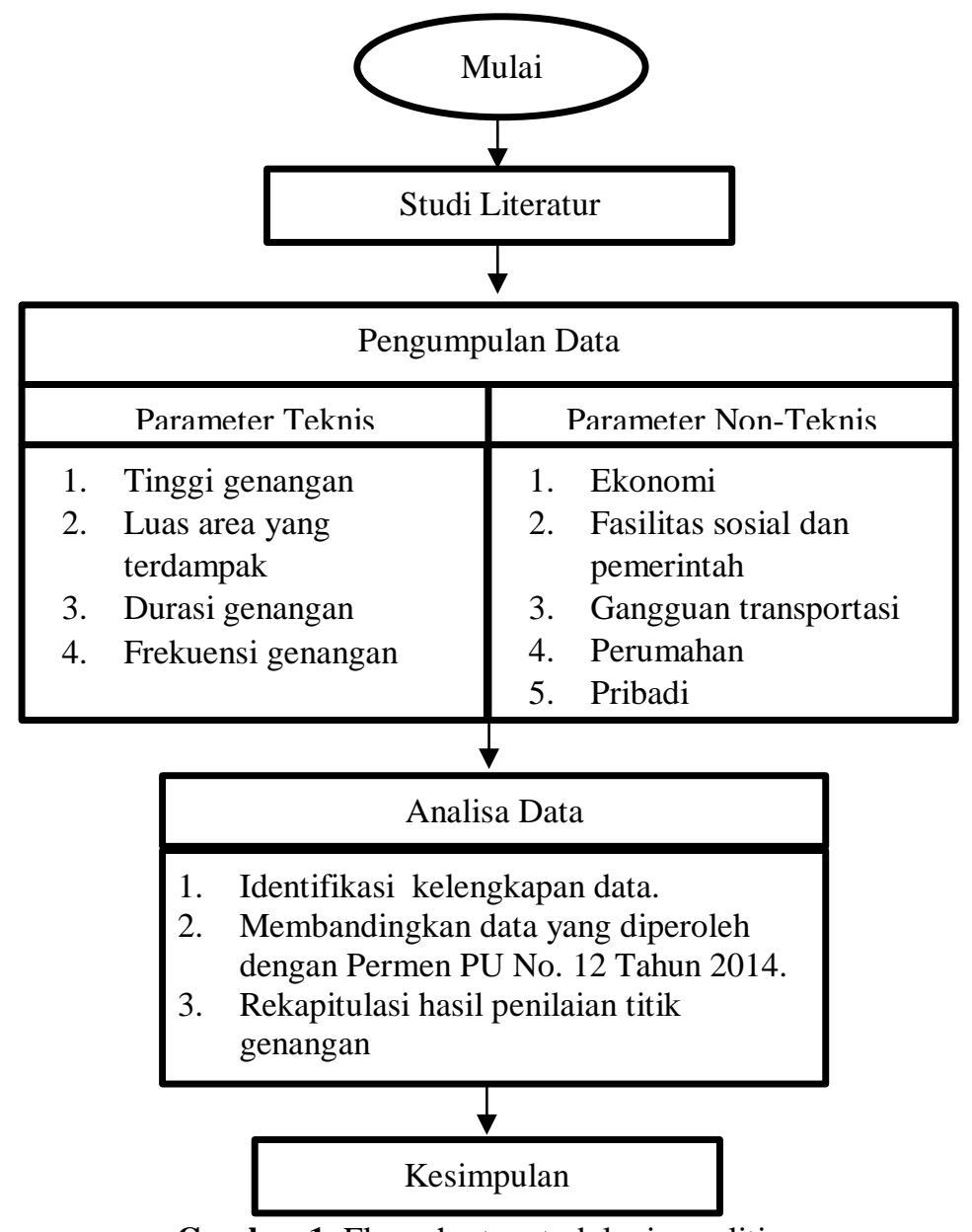

Gambar 1. Flow chart metodologi penelitian

\section{Parameter Genangan}

Parameter genangan meliputi tinggi genangan (m), Luas genangan (Ha), Lamanya genangan dalam 1 jam, serta frekuensi genangan dalam 1 tahun. Kriteria parameter genangan seperti dalam Tabel 1.

Tabel 1. Kriteria parameter genangan

\begin{tabular}{|c|c|c|}
\hline Parameter Genangan & Nilai & Persentase Nilai \\
\hline Tinggi genangan $(\mathrm{m})$ : & 35 & \\
\hline$>0,50$ & & 100 \\
\hline $0,30-0,50$ & & 75 \\
\hline $0,20-0,30$ & & 50 \\
\hline $0,10-0,20$ & & 25 \\
\hline$<0,10$ & & 0 \\
\hline Luas genangan $(\mathrm{Ha})$ : & 25 & \\
\hline$>8$ & & 100 \\
\hline $4-8$ & & 75 \\
\hline $2-4$ & & 50 \\
\hline $1-2$ & & 25 \\
\hline$<1$ & & 0 \\
\hline Lamanya genangan (jam): & 20 & \\
\hline$>8$ & & 100 \\
\hline $4-8$ & & 75 \\
\hline $2-4$ & & 50 \\
\hline $1-2$ & & 25 \\
\hline$<1$ & & 0 \\
\hline Frekuensi genangan: & 20 & \\
\hline Sangat sering (10 kali/tahun) & & 100 \\
\hline Sering (6 kali/tahun) & & 75 \\
\hline Kurang sering (3 kali/tahun) & & 50 \\
\hline
\end{tabular}




\begin{tabular}{lcc}
\hline \multicolumn{1}{c}{ Parameter Genangan } & Nilai & Persentase Nilai \\
\hline Jarang (1 kali/tahun) & 25 \\
Tidak pernah & 0 \\
\hline
\end{tabular}

Sumber: [1]

\section{Parameter Ekonomi}

Fasos (fasilitas sosial), fasum (fasilitas umum), daerah pertanian, perkotaan, pertamanan, kawasan industri, dan perumahan merupakan bagian yang diamati dalam memperkirakan kerugian yang berpengaruh terhadap fasilitas ekonomi. Kriteria parameter ekonomi seperti dalam Tabel 2.

Tabel 2. Kriteria kerugian ekonomi

\begin{tabular}{lcc}
\hline \multicolumn{1}{c}{ Parameter } & Kerugian & Nilai \\
\hline Terjadi banjir pada kawasan komersial perkantoran padat dan industri & Tinggi & 100 \\
$\begin{array}{l}\text { Terjadi banjir pada kawasan komersial perkantoran padat dan industri } \\
\text { yang kurang padat }\end{array}$ & Sedang & 65 \\
$\begin{array}{l}\text { Terjadi banjir yang mempengaruhi kawasan perumahan dan/atau } \\
\text { kawasan pertanian }\end{array}$ & Kecil & 30 \\
$\begin{array}{l}\text { Terjadi genangan air/banjir pada daerah yang jarang penduduknya dan } \\
\text { bukan daerah komersil }\end{array}$ & Sangat Kecil & 0 \\
\hline
\end{tabular}

Sumber: [1]

Mengacu pada [8], maka kepadatan penduduk di Kecamatan Bogor Tengah diklasifikasikan sebagai kawasan sangat padat. Data kepadatan penduduk dan tingkat kepadatan penduduk dikategorikan dalam Tabel 3.

Tabel 3. Klasifikasi tingkat kepadatan

\begin{tabular}{cc}
\hline Kepadatan Penduduk $\left(\mathrm{Jiwa} / \mathrm{km}^{2}\right)$ & Tingkat Kepadatan \\
\hline $0-50$ & Tidak Padat \\
$51-250$ & Kurang Padat \\
$251-400$ & Cukup Padat \\
$>400$ & Sangat Padat \\
\hline
\end{tabular}

Sumber: [8]

\section{Parameter Gangguan Sosial dan Fasilitas Pemerintah}

Parameter gangguan sosial dan fasilitas pemerintah, seperti: kerusakan fasilitas pemerintahan, kesehatan masyarakat, dan kerusakan ligkungan. Kriteria parameter gangguan sosial dan fasilitas pemerintahan seperti dalam Tabel 4.

Tabel 4. Kriteria kerugian fasilitas sosial dan fasilitas pemerintahan

\begin{tabular}{lcc}
\hline \multicolumn{1}{c}{ Parameter } & Kerugian & Nilai \\
\hline $\begin{array}{l}\text { Terjadi genangan pada kawasan yang banyak pelayanan fasilitas } \\
\text { pemerintah dan fasilitas sosial }\end{array}$ & Tinggi & 100 \\
$\begin{array}{l}\text { Terjadi genangan pada kawasan yang sedikit pelayanan fasilitas } \\
\text { pemerintah dan fasilitas sosial }\end{array}$ & Sedang & 65 \\
$\begin{array}{l}\text { Terjadi genangan pada kawasan dengan pelayanan fasilitas } \\
\text { pemerintah dan fasilitas sosial terbatas }\end{array}$ & Kecil & 30 \\
Tidak ada fasilitas sosial dan fasilitas pemerintah & Sangat Kecil & 0 \\
\hline
\end{tabular}

Sumber: [1]

\section{Parameter Kerugian dan Gangguan Transportasi}

Berdasarkan jaringannya transportasi dapat diketegorikan menjadi padat, kurang padat, dan terbatas dilihat dari keterpaduan antara sistem transportasi [10]. Kriteria parameter kerugian dan gangguan transportasi menurut [1] dapat dilihat pada Tabel 5. 
Tabel 5. Kriteria kerugian dan gangguan transportasi

\begin{tabular}{lcc}
\hline \multicolumn{1}{c}{ Parameter } & Kerugian & Nilai \\
\hline Terjadi genangan pada kawasan jaringan transportasi padat & Tinggi & 100 \\
Terjadi genangan pada kawasan jaringan transportasi kurang padat & Sedang & 65 \\
Terjadi genangan pada kawasan jaringan transportasi terbatas & Kecil & 30 \\
Tidak ada jaringan jalan & Sangat Kecil & 0 \\
\hline
\end{tabular}

Sumber: [1]

Menurut [11] dalam [12] dalam penelitiannya, moda transportasi umum dapat dijadikan indikator kepadatan jaringan transportasi. Indikator kepadatan jaringan transportasi dapat dilihat pada Tabel 6. Rasio arus terhadap kapasitas merupakan definisi derajat kejenuhan, nilai derajat kejenuhan menunjukan apakah mempunyai masalah kapasitas/tidak pada segmen jalan tersebut [13]. Kemacetan terjadi akibat kapasitas jalan terlampaui dengan persamaan tingkat pelayanan yaitu V/C (volume/capasitas) mendekati 1, dimana nilai ideal untuk V/C pada suatu akses jalan sebesar <0,75 [14].

Tabel 6. Indikator kepadatan jaringan transportasi

\begin{tabular}{lc}
\hline \multicolumn{1}{c}{ Parameter } & Ukuran \\
\hline Jarak jalan kaki ke shelter & \\
Wilayah padat & $300-500$ menit \\
Wilayah kurang padat & $500-1000$ menit \\
Kecepatan Perjalan & \\
Daerah padat dan mix traffic & $10-12 \mathrm{~km} / \mathrm{jam}$ \\
Daerah kurang padat & $25 \mathrm{~m} / \mathrm{jam}$ \\
\hline
\end{tabular}

Sumber: [11]

\section{Parameter Kerugian Pada Daerah Perumahan}

Berdasarkan [15] tentang perumahan dan kawasan pemukiman disebutkan bahwa pemukiman kumuh yaitu pemukiman yang tidak layak huni akibat ketidakteraturan bangunan, tingkat kepadatan bangunan tinggi, serta terdapat sarana dan pra-sarana yang tidak memenuhi syarat. Penelitian [16] mengkategorikan pemukiman kumuh dengan beberapa kondisi yaitu pemukiman sangat ramai dan ditandai dengan perumahan dan populasi yang berkepadatan tinggi, pemukiman terbuat dari struktur berkualitas buruk dan bobrok, penghuninya mengalami kemiskinan tingkat tinggi dan pengucilan sosial, penghuninya tidak memiliki jaminan kepemilikan lahan, penghuninya memiliki kekurangan pelayanan dasar, dan memiliki lingkungan hidup yang tidak sehat. Kriteria kerugian pada daerah perumahan menurut [1] dapat dilihat pada Tabel 7.

Tabel 7. Kriteria kerugian pada daerah perumahan

\begin{tabular}{lcc}
\hline \multicolumn{1}{c}{ Parameter } & Kerugian & Nilai \\
\hline Terjadi pada perumahan padat sekali & Tinggi & 100 \\
Terjadi pada perumahan kurang padat & Sedang & 65 \\
Terjadi pada daerah yang terdapat beberapa bangunan perumahan & Kecil & 30 \\
Perumahan pada daerah banjir & Sangat Kecil & 0 \\
\hline
\end{tabular}

Sumber: [1]

Menurut [17] dalam [18] klasifikasi kawasan perumahan dibagi menjadi 3 klaster dengan pengkategorian sebagai berikut : (a) luas pemukiman rata-rata $<40 \%$ dikategorikan kawasan kurang padat, (b) luas pemukiman rata-rata 40\%-60\% kawasan sedang dan (c) untuk luas pemukiman rata-rata $>60 \%$ dikategorikan sebagai kawasan padat.

Parameter Kerugian Hak Milik Pribadi

Kriteria kerugian hak milik pribadi/rumah tangga menurut [1] dapat dilihat pada Tabel 8. Pemerintah membagi jenis kerugian ke dalam empat kategori. Pembagian ini menurut nilai kerugian yang dialami korban banjir mulai dari kecil, sedang dan tinggi. 
Tabel 8. Kriteria kerugian hak milik pribadi

\begin{tabular}{lcc}
\hline \multicolumn{1}{c}{ Parameter } & Kerugian & Nilai \\
\hline Jika kerugian lebih dari $80 \%$ nilai milik & Tinggi & 100 \\
Jika kerugian $80 \%$ dari nilai milik pribadi & Sedang & 65 \\
Jika kerugian kurang dari $40 \%$ milik pribadi & Kecil & 30 \\
Tidak ada kerugian milik pribadi & Sangat Kecil & 0 \\
\hline
\end{tabular}

Sumber: [1]

\section{Hasil dan Pembahasan}

Secara Geografis Kecamatan Bogor Tengah terletak diantara 6.34'55,4"-6.36'35,2" LS dan 106.47'19,8"-106.47'19,8” BT. Dengan jumlah penduduk sekitar 104.853 jiwa dan luas sebesar 851 Ha, Kecamatan Bogor Tengah dapat dikategorikan sebagai kawasan padat penduduk. Kecamatan Bogor Tengah terletak dekat pusat kota yaitu hanya berjarak $2 \mathrm{~km}$ dari pusat kota. Kecamatan Bogor Tengah dialiri oleh dua sungai besar yakni Sungai Cisadane sebagai batas wilayah dengan Kecamatan Bogor Barat, dan Sungai Ciliwung yang berada di tengah kota. Kecamatan Bogor Tengah merupakan wilayah perbukitan bergelombang dengan ketinggian bervariasi antara 200 s.d. $300 \mathrm{~m}$ di atas permukaan laut. Penggunaan lahan di Kecamatan Bogor Tengah berupa lahan pertanian seluas 0,45 Ha $(0,08 \%)$, bangunan umum (kantor dan pertokoan) seluas 15,61 Ha (2,87\%), pemakaman 2,95 Ha $(0,54 \%)$, perumahan/pemukiman seluas 524,24 $\mathrm{Ha}(96,5 \%)$, dan lain lain.

Beberapa wilayah di Kecamatan Bogor Tengah masuk dalam daerah rawan banjir. Penyebab utama permasalahan sistem drainase di Kecamatan Bogor Tengah yaitu (a) Tingginya intensitas curah hujan. (b) Belum terintegrasinya sistem drainase satu wilayah dengan wilayah lain disekitarnya. (c) Mix Drain, Terjadi akibat penyimpangan perilaku pengelolaan sampah dan limbah serta penggunaan lahan yang tidak tepat di areal pemukiman yang padat penduduk dan pusat kegiatan perdagangan/pasar tradisional. (d) Pendangkalan dan penyempitan jaringan drainase makro.

Survei identifikasi titik genangan memiliki fungsi sebagai alat verifikasi mengenai kawasan yang akan dijadikan prioritas penanganan banjir. Berdasarkan masterplan 2018 di Kecamatan Bogor Tengah terdapat 3 Kelurahan dengan 5 titik genangan/banjir yang dijadikan analisa penentuan proritas. Pembahasan setiap kelurahan disajikan pada uraian berikut.

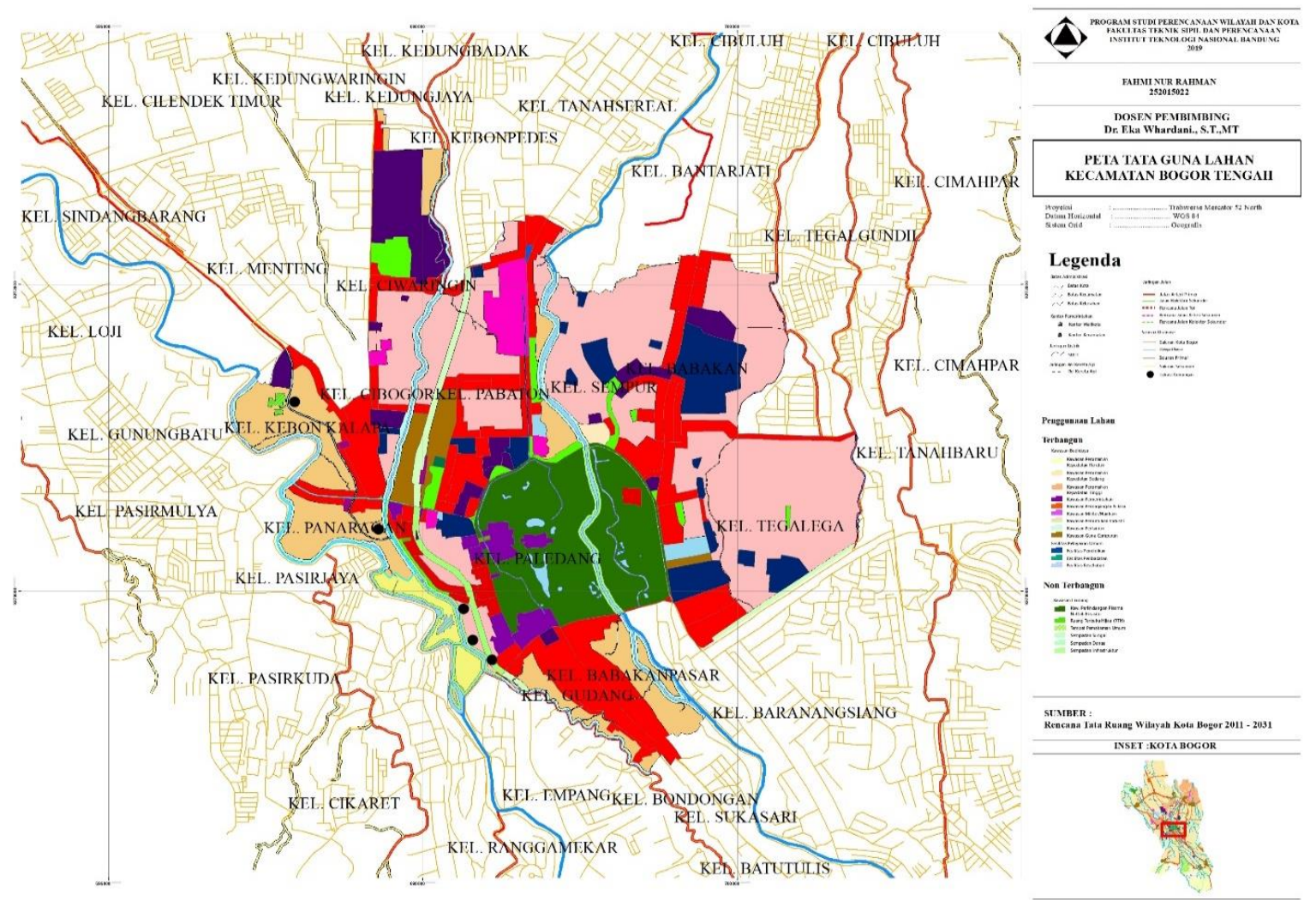

Gambar 2. Peta Tata Guna Lahan Kecamatan Bogor Tengah Sumber: [2] 


\section{Kelurahan Panarangan}

Titik banjir berada daerah tidak produktif tepatnya di RW 07 RT 03, tepat di bantaran Sungai Cisadane. Peta tata guna lahan disajikan pada Gambar 2. Berdasarkan hasil wawancara dengan warga setempat dengan ketua RW 07, banjir terakhir terjadi pada tahun 2018 yang menyebabkan sekitar 6 sampai 7 rumah terendam. Genangan yang terjadi beradius 2,1 Ha dengan lama genangan berkisar 4-8 jam, menurut warga setempat tinggi genangan berkisar sepinggang orang dewasa atau ketinggian air mencapai 1 meter. Periode genangan yang terjadi di Kelurahan Panarangan sekitar 1-2 kali/tahun. Di kawasan tersebut tidak terdapat fasilitas sosial/fasilitas pemerintah yang terkena dampak akibat genangan, selain itu genangan yang terjadi bukan pada jalur transportasi. Kerugian dirasakan langsung oleh mayarakat setempat dikarnakan genangan terjadi di pemukiman sangat padat dan lebih dari $80 \%$ kerugian merupakan hak milik pribadi. Tabel 9-10 menyajikan hasil rekapitulasi penilaian untuk setiap parameter banjir di Kelurahan Panarangan.

Tabel 9. Penentuan parameter genangan

\begin{tabular}{lcccc}
\hline & \multicolumn{4}{c}{ Kelurahan Panaragan } \\
Parameter Genangan & RW 6 & Skor & RW 7 & Skor \\
\hline Tinggi & $\mathrm{a}$ & 100 & $\mathrm{a}$ & 100 \\
Luas & $\mathrm{e}$ & 0 & $\mathrm{e}$ & 0 \\
Durasi & $\mathrm{b}$ & 75 & $\mathrm{~b}$ & 75 \\
Frek & $\mathrm{d}$ & 25 & $\mathrm{~d}$ & 25 \\
\hline Rekapitulasi & \multicolumn{5}{c}{55} \\
\hline
\end{tabular}

Setelah dilakukan rekapitulasi pembobotan parameter genangan, Kelurahan Panarangan RW 6 memperoleh bobot parameter genangan sebesar 55, dimana angka tersebut diperoleh dari pembobotan yang terdapat di Permen PU No. 12 tahun 2014 sebagai berikut: (1) tinggi genangan 35\%, (2) luas genangan 25\%, (3) durasi genangan 20\%, (4) frekuensi genangan 20\%. Pembobotan tersebut di kalikan dengan nilai skor yang diperoleh/total skor (skor/total skor x pembobotan) sehingga diperoleh hasil: (1) tinggi genangan sebesar 35 point, (2) luas genangan sebesar 0 point, (3) durasi genangan sebesar 15 point, (4) frekuensi genangan sebesar 5 point. Langkah selanjutnya yaitu pembobotan yang sudah diperoleh dijumlahkan sehingga diperoleh hasil sebesar 55 point untuk Kelurahan Panarangan RW 06 dan RW 07. Tabel 10 menyajikan rekapitulasi penilaian di Kelurahan Panaragan.

Tabel 10. Rekapitulasi penilaian Kelurahan Panaragan

\begin{tabular}{lcccc}
\hline Parameter Penentuan Prioitas & RW 6 & Skor & RW 7 & Skor \\
\hline Genangan & & 55 & & 55 \\
Ekonomi & d & 0 & d & 0 \\
Sosial dan fasilitas pemerintah & d & 0 & d & 0 \\
Transportasi & d & 0 & d & 0 \\
Perumahan & $\mathrm{a}$ & 100 & $\mathrm{a}$ & 100 \\
Kerugian hak milik pribadi & $\mathrm{a}$ & 100 & $\mathrm{a}$ & 100 \\
\hline Rekapitulasi & & 255 & & 255 \\
\hline
\end{tabular}

\section{Kelurahan Paledang}

Titik genangan tersebut berada di kawasan pemukiman dan pertanian tepatnya di Kelurahan Paledang RW 5 (RT 02,03,04), RW 06 (RT 02,03,04,05), dan RW 09. Genangan yang terjadi disebabkan oleh saluran irigasi Cipakancilan yang berasal dari Sungai Cibalok dan Sungai Cisadane (Bendung Empang). Saluran ini merupakan saluran induk yang direncanakan untuk mengaliri daerah irigasi di Bogor bagian Utara dan daerah hilirnya. Air yang masuk dari Sungai Cisadane (Bendung Empang) dapat diatur menggunakan pintu air, namun air dari arah sungai Cibalok tidak bisa dikendalikan. Hal ini memungkinkan terjadinya peluapan di ruas saluran induk.

Berdasarkan hasil wawancara dengan masyarakat setempat, genangan yang terjadi berdampak $<1$ Ha dengan lama genangan berkisar 1-2 jam, tinggi genangan yang terdapat di Kelurahan Paledang berkisar antara 30-40 centimeter dengan priode genangan sekitar 1-2 kali/tahun. Pada saat terjadi genangan di kawasan tersebut, menimbulkan dampak terhadap fasilitas sosial/fasilitas pemerintah. Selain itu, kerugian berdampak langsung terhadap mayarakat dikarenakan genangan terjadi di pemukiman sangat padat. 


\section{Kelurahan Kebon Kelapa}

Genangan yang terdapat di Kelurahan Kebon Kelapa berada di kawasan pemukiman tidak padat penduduk dan pertanian tepatnya di RW 6 dan RW 7 Kelurahan Kebon Kelapa. Kasus genangan di RW 6 dan RW 7 Kelurahan Kebon Kelapa pada dasarnya merupakan dampak dari adanya pembangunan perumahan di kawasan sungai Cisadane, sehingga menimbulkan banjir pada periode ulang tertentu. Berdasarkan hasil wawancara dengan pihak kelurahan dan warga setempat terjadi genangan dengan ketinggian air sekitar 5 meter dengan luas genangan yang terkena dampak sebesar 1,3 Ha. Lamanya genangan yang terdapat di Kelurahan Kebon Kelapa berkisar 6-8 jam, dengan periode genangan 10 kali dalam 1 tahun. Pada saat terjadi genangan di kawasan tersebut, tidak menimbulkan dampak terhadap fasilitas sosial/fasilitas pemerintah. Selain itu ketika terjadinya genangan tidak mengganggu jalur transportasi di Kelurahan Kebon Kelapa.

\section{Penentuan Prioritas Penanganan}

Rencana indikasi program terdapat 2 alternatif pilihan timeline pembangunan, yaitu berdasarkan nilai skoring dan rencana biaya. Jika pengerjaan program mengikuti nilai skoring, maka prioritas pelaksanaan berdasarkan nilai skoring terbesar. Sedangkan jika pengerjaan program mengikuti rencana biaya, maka pelaksanaan berdasarkan ketersediaan biaya.

Jumlah nilai maksimum dari keenam kriteria tersebut di atas berikas antara 0 sampai dengan 600 . Nilai tertinggi merupakan kawasan dengan prioritas utama, makin rendah nilainya makin rendah pula prioritasnya. Berdasarkan hasil perhitungan diperoleh skor berkisar 71,25-255, dimana nilai tertinggi terdapat di Kelurahan Panarangan Rw 6,7 dengan skor 255 dan nilai terendah terdapat di Kelurahan Paledang Rw 9 dengan skor 71,25. Sehingga dari hasil tersebut menunjukan bila perencanaan disesuaikan dengan nilai tertinggi dari nilai skoring maka prioritas penanganan seperti terdapat pada Tabel 11.

Tabel 11. Rekapitulasi prioritas penanganan banjir

\begin{tabular}{lc}
\hline \multicolumn{1}{c}{ Lokasi } & Skor \\
\hline Kelurahan Panaragan RW 6,7 & 255 \\
Kelurahan Paledang RW 5 & 235 \\
Kelurahan Paledang RW 6 & 205 \\
Kelurahan Kebon Kelapa RW 6 & 131,25 \\
Kelurahan Paledang RW 9 & 71,25 \\
\hline
\end{tabular}

\section{Kesimpulan}

Berdasarkan hasil rekapitulasi prioritas penanganan banjir di Kecamatan Bogor Tengah dilaksanakan mulai dari Kelurahan Panarangan RW 6 dan 7 hingga prioritas paling rendah dilaksanakan di Kelurahan Paledang RW 9. Artinya di Kelurahan Panarangan RW 6 dan 7 bila terjadi hujan dan menimbulkan genangan maka kawasan tersebut memiliki dampak yang lebih besar dan harus segera ditangani. Pemerintah harus menyiapkan perencanaan dan antisipasi jika terjadi hujan yang menyebabkan banjir pada daerah prioritas tersebut.

\section{Referensi}

[1] Peraturan Menteri Pekerjaan Umum Nomor 12, tentang Penyelenggaraan Sistem Drainase Perkotaan, 2014.

[2] Badan Perencanaan Pembangunan Daerah Kota Bogor, Masterplan Drainase Kota Bogor Tahun 2018, Bappeda Kota Bogor, Bogor, 2018.

[3] Sinukaban, N, Menjinakkan Ciliwung Untuk Mengamankan Jakarta, Kompas, 2005.

[4] Pontoh N.K, Sudrajat D.J, "Hubungan Perubahan Penggunaan Lahan Dengan Limpasan Air Permukaan: Studi Kasus Kota Bogor," Jurnal Perencanaan Wilayah Kota, Bandung, Vol. 16/No. 3, hlm.44-56, 2005.

[5] Suripin, Pelestarian Sumberdaya Tanah dan Air, Penerbit Andi Yogyakarta, Yogyakarta, 2002.

[6] Baume., Larry S, Internal Structure of the City, Oxford University Press, New York, 1971.

[7] S. Lili, Pemenafaatan Teknik Pengindraan Jauh Untuk Mengidentifikasi Kerentanan dan Resiko Banjir, Bandung, 2008.

[8] Dibyosaputro. P, "Flood Susceptibility and Hazard Survey of The Kudus Prawata-Welahan. Area, Central Java, Indonesia," Thesis, ITC, Encshede, The Netherlands, 1984.

[9] R. Anita., W. Eka., S. A. Lina, "Analisis Penentuan Skala Prioritas Genangan atau Banjir Di Kecamatan Bogor Selatan," Jurnal Teknologi Lingkungan Lahan Basah, Vol 07, No 2, hal: 081091, 2019. 
[10] Jinca, Transpotasi Laut Indonesia Analisis Sistem \& Studi Kasus, Surabaya: Berlian Internasional, 2011.

[11] Abubakar I, Menuju Lalu Lintas dan Angkutan Jalan yang Tertib, Jakarta: Direktorat Jendral Perhubungan Darat, 1995.

[12] Ayu K. M., Robbiatul A., Riyanto B., Kusuma A. I, "Evaluasi Efektifitas dan Efisiensi Angkutan Umum Di Kawasan Tembalang," Jurnal Teknik Sipil, Fakultas Teknik Universitas Diponogoro, Semarang, 2013.

[13] Manual Kapasitas Jalan Indonesia (M.K.J.I.), 1997.

[14] A. Alhadar, "Analisis Kerja Jalan Dalam Upaya Mengatasi Kemacetan Lalu Lintas Pada Ruas Simpang Bersinyal Di Kota Palu," Jurnal SMARTek, Vol.9 2011: 327-336, 2011.

[15] Undang-Undang Republik Indonesia nomor 1 Tahun 2011 tentang Perumahan dan Kawasan Pemukiman.

[16] H. Aulia, "Evaluasi Keberhasilan Taman Lingkungan Di Perumahan Padat Sebagai Ruang Terbuka Publik Studi Kasus: Taman Lingkungan Di Kelurahan Galur Jakarta Pusat,"Jurnal Perencanaan Wilayah Kota," Jakarta Pusat, Vol, 24 No. 2, hlm 109-124, 2013.

[17] Fitrianingrum, M.E, Identifkasi Kualitas Lingkungan Pemukiman dan Persebaran Kawasan Permukiman Kumuh dengan Sistem Informasi Geografis (Studi Kasus: Semarang Tengah), Universitas Diponegoro, Semarang, 2011.

[18] H. Nizma., S. Bambang., Dr. Prasetyo Y, Analisis Perbandingan Kepadatan Pemukiman Menggunakan Klasifikasi Supervised dan Segmentasi (Studi Kasus: Kota Bandung), Universitas Diponogoro, Semarang, 2015. 